\title{
The effect of financial distress on earning management practices using classification shifting: The moderating effect of good corporate governance
}

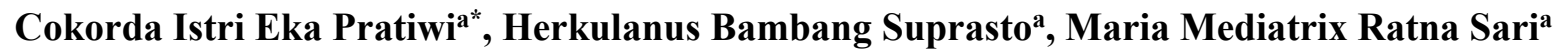 \\ and Dodik Ariyanto ${ }^{a}$
}

\begin{tabular}{l}
$\frac{{ }^{a} \text { Fakultas Ekonomi and Bisnis Univer }}{\text { C H R O N I C L E }}$ \\
\hline Article history: \\
Received June 18, 2021 \\
Received in revised format June \\
282021 \\
Accepted July 22021 \\
Available online \\
July 2 2021 \\
\hline Keywords: \\
Earnings management \\
Classification shifting \\
Financial distress \\
Independent commissioners \\
Audit committee
\end{tabular}

\section{Introduction}

The full financial statements consist of statements of end-of-period financial positions, statements of income and other comprehensive income during the period, reports of changes in equity during the period, statements of cash flows during the period, notes on financial statements, and statements of financial position at the beginning of the nearest period. From the many reports reported, the profit and loss statement is a report that can reflect the company's achievements. This is supported by Astika (2010) which says that when viewed from investor habits, investors do focus more often on profit information presented in the profit and loss statement. The reason is because the amount of profit generated can provide information about the company's ability to generate profit derived from the company's operations as well as those derived from other events that are not permanent. Such investor habits can give rise to opportunistic behavior from management to manipulate the profit figures to be reported in the financial statements (Debbianita, 2016). Given the superior control that managers have in reporting and collecting company-specific information over external information users, managers have the opportunity to present the company's revenue in a way that is best suited for the company or for the manager itself or commonly known as profit management (Ghazali et al., 2015). Earnings management is also known as "cooking the books" - an act in which a person illegally manipulates the content or numbers in a financial statement. Schipper in Kanakriyah et

* Corresponding author

E-mail address: cokekaa96@gmail.com (C. I. E. Pratiwi)

C 2022 Growing Science Ltd. All rights reserved.

doi: $10.5267 /$ j.ac.2021.7.002 
al. (2017) defines it as a deliberate intervention in the financial reporting process to achieve personal goals or in other words, profit management can be categorized as opportunistic behavior when viewed from motivations to be achieved such as bonus motivation or CEO turnover motivation. Earnings management occurs when a manager changes a financial statement that will mislead some stakeholders about the underlying economic performance of the company or affect the outcome of a contract that relies on reported accounting figures (Abbadi et al., 2016). Therefore, earnings management can improve biased information in financial statements and can annoy report users who believe in contrived profit figures as actual numbers. This manipulation negatively impacts the future of the company, as one of the parties who use financial statements to make decisions causes incorrect decisions (Supardi \& Asmara, 2019).

One of the factors that is strongly suspected to support the occurrence of profit management practices is financial distress. Financial distress is a condition in which the company's operating results are not sufficient to meet the company's obligations (insolvency)or in other words the company has financial difficulties to pay its obligations. The occurrence of financial distress can also be said to be a poor financial performance of the company and encourage shareholders to change managers because it is considered incapable of managing the company properly (Noviantari and Ratnadi, 2015). Companies experiencing financial distress will take decisions to address conditions such as termination of operations, manufacturing, or division, reduction of production, not paying dividends, reduction of employees and even frequent profit management (Gunawan et al., 2014). Financial distress itself has become a well-known topic in the field of finance, where the financial health of a company is said to be an important indicator for investors interested in knowing the company's performance. Many stakeholders such as creditors, suppliers, investors, customers, and employees are reluctant to deal with companies experiencing financial difficulties (Kazemian et al., 2017). When managers know of financial distress in the company, in addition to reducing costs, profit management is a practical way to respond to financial distress (Supardi and Asmara, 2019). In addition, Jacoby et al.,(2019) revealed that financially distressed public companies will be motivated to engage in profit management practices to avoid default. Financial distress research on profit management practices conducted by Ranjbar and Amanollahi (2018) states that in the face of financial distress, companies manipulate accounting profits as performance measurement items. In addition, companies experiencing financial distress tend to adopt profit management practices to prevent the continued underperforming financial situation and risk being excluded from the Tehran Stock Exchange. The corresponding results were also found by Jacoby et al. (2019) which found that private companies in China that experience financial distress are more involved in profit management than financially sound companies with the aim of reducing the potential negative influence of financial distress. Research from Campa (2019) provides empirical evidence that companies with severe levels of financial distress will conduct profit management regardless of whether the company is a public go-to company or not. It is further explained that these companies tend to do profit management through real profit management because accrual profit management will most likely be easier to detect. Furthermore, Li et al., (2020) proved that after considering between relative costs and risks, Chinese listed companies experiencing financial distress expressed a tendency to manipulate accrual profit rather than real.

In Indonesia, Damayanti and Kawedar (2018), Gupta and Suartana (2018), Putri and Rachmawati (2018), and Kurniawati and Panggabean (2020) proved that financial distress has an effect on profit management practices. The results indicate that companies experiencing financial difficulties will conduct profit management, where the higher the level of financial difficulty, the behavior of profit management will also increase. Furthermore, according to Kurniawati and Panggabean (2020), the healthier the company, the greater the real profit management. On the contrary, the lower the financial health of a company, the greater the amount of accrual profit management performed. The profit management scandal that still exists to this day makes the public aware of the importance of good corporate governance. Good corporate governance is expected to reduce or suppress profit management practices and create a clean and healthy business world. The corporate governance structure consists of functions and processes established to oversee and influence the company's management actions. The role of this mechanism in relation to financial reporting is to ensure compliance with mandated reporting requirements and to maintain the credibility of the company's financial statements (Dechow et al., Davidson, 2005). This study examined profit management practices using classification shifting tools, i.e. deliberate misclassification of some recurring costs (e.g. cost of sales and sales, general and administrative costs) as non-recurring in profit and loss statements with the aim of increasing core profit. This profit management tool is an important work of McVay (2006)which is considered a milestone in the literature of classification shifts, in which McVay was the first researcher to develop an expectation model to capture manipulation through cost classification errors in profit and loss statements. Furthermore, this study expands the research on classification shifting conducted in Indonesia by Cahyaningtyas and Husnaini (2017) provides empirical evidence that managers at manufacturing companies on the Indonesia Stock Exchange indicated by financial distress are proven to conduct profit management practices using classification shifting with the aim of showing good performance in order to obtain funds from third parties in order to be used for the company's operational activities. Then, a subsequent study conducted by Debbianita (2016) which showed different results from previous research, found that in Malaysia, Singapore, Indonesia and Filiphina there was no profit management practice through shifting classification.

The differences in this study lie in the company's industry, research years, data analysis techniques, as well as the addition of moderation variables that also refer to Debbianita (2016) which also uses moderation variables. However, the moderation variables in this study used different proxies, namely using an independent board of commissioners and an audit committee. The reason for using variables of the independent board of commissioners and audit committees is because both boards are important elements in the implementation of good corporate governance that is expected to suppress profit management 
practices to create a clean and healthy world of work. Furthermore, this research was conducted on property, real estate, and building construction sector companies listed on the Indonesia Stock Exchange (IDX) for the period 2015-2019 with data analysis techniques using Eviews software tools.

\section{Literature review and hypotheses development}

Financial distress is the inability of the company to fulfill its obligations or in other words experience insolvency. When managers know of financial distress in the company, in addition to reducing costs, profit management is a practical way to respond to financial distress (Supardi \& Asmara, 2019). In addition, Jacoby et al., (2019) revealed that financially distressed public companies will be motivated to engage in profit management practices to avoid default and opportunistic managers will seek to improve their well-being by conducting profit management. Previous empirical evidence from Cahyaningtyas and Husnaini (2017) found that managers at financial distress companies tend to practice profit management using classification shifting. This indicates that managers at financial distress companies are trying to perform well to obtain funds from third parties and for management to receive bonuses and other compensation. Then, Nagar and Sen (2017) proved that managers of companies experiencing financial distress proved classification shifting by moving core expenses to special items to increase core earnings with an average shifting of about $\$ 1.9 \mathrm{~m}$ per year. Based on the description, it is concluded that when the company is in financial distress condition, the manager tends to practice profit management as a form of effort to protect the position or position of the manager and to keep the company afloat and look to perform well.

\section{H1: Financial Distress affects Profit Management Practices Using Classification Shifting.}

The Board of Commissioners is the highest internal control mechanism responsible for monitoring the actions of top management (Dewi et al., 2019). Based on OJK Regulation No. 33 of 2014, the board of commissioners consists of two members of the board of commissioners, one of whom is an independent commissioner. An independent commissioner is a member of the board of commissioners who has no financial relationship, management, share ownership and or controlling holder or other relationship that may affect his ability to act independently (Amelia \& Hernawati, 2016). Previous empirical evidence from Zalata and Roberts (2016), Idris et al. (2018), and Busirin et al. (2015) proves that the existence of independent commissioners introduce profit management practices because it is an important element in corporate governance and is considered a major internal mechanism in reducing agency conflicts. The results are also in accordance with the duties of the board of commissioners to supervise and be responsible for supervision of management, the course of management in public companies and advising the board of directors and ensuring the company implements good corporate (Dewi et al., 2019). Based on the description, it was concluded that the influence of financial distress conditions on profit management practices will be weakened by the existence of an independent board of commissioners because these boards will supervise the performance of management and act independently without any influence from the internal parties of the company, so as to minimize fraud in financial reporting.

\section{$\mathbf{H}_{2}$ : Independent Board of Commissioners Weakens Financial Distress's Influence on Profit Management Practices Using Classification Shifting,}

Based on OJK Regulation No. 55 of 2015, the audit committee is a committee formed by and responsible to the board of commissioners in helping to carry out the duties and functions of the board of commissioners. Each public company is required to have an audit committee, consisting of at least three members from independent commissioners and parties from outside public companies and chaired by independent commissioners. Previous empirical evidence from Mansor et al. (2013), Marsha and Ghozali (2017), Dwiyanti and Astriena (2018), and Zehri and Zgarni(2020) prove that the audit committee is able to reduce profit management practices because companies with more audit committee members will be able to better monitor management performance and supervise the process of preparing financial reporting. The results are supported by the audit committee's duties which include reviewing accounting policies implemented by the company, assessing internal controls, reviewing external reporting systems and regulatory compliance (Chrisdianto, 2013). Based on the description, it was concluded that the influence of financial distress conditions on profit management practices will be weakened by the existence of an audit committee due to the larger number of audit committees, tending to perform better in monitoring management performance and financial reporting processes. That is because the audit committees can exchange expertise and experience with each other to minimize the occurrence of profit management practices.

\section{H3: Audit Committee Weakens Financial Distress Influence on Profit Management Practices Using Classification Shifting.}

\section{Method}

The location of this research was conducted on property, real estate,and building construction companies listed on the Indonesia Stock Exchange (IDX) with a research period of 2015-2019. This study uses secondary data that can be obtained from annual reports and financial statements on property, real estate, and building construction sector companies in IDX for the period 2015-2019 which can be downloaded through www.idx.co.id and by accessing their respective company's website. The population in this study is all property, real estate, and building construction sector companies in the period 
2015-2019. The method of determining samples used in this study is to use purposive sampling method, the selection of non-random samples whose information is obtained with certain considerations. The criteria used are as follows:

1) Property, real estate, and building construction sector companies listed on the Indonesia Stock Exchange (IDX) in 2015-2019.

2) Companies that publish annual reports and financial statements for the period 2015-2019 respectively.

3) There is information on financial distress and good corporate governance in annual reports and financial statements.

This research data analysis method uses data panel analysis as a data processing tool using Eviews 10 software. Analysis using a data panel is a combination of time series and cross section data (Pandoyo, 2018). Systematically the model regression equation can be written as follows.

$$
\begin{array}{ll}
M L=\alpha+\beta_{1} F D+\beta_{2} P D K I+\beta_{3} P K A+\beta_{4} F D \times P D K I+\beta_{5} F D \times P K A+\varepsilon \\
\text { where } & =\text { Classification Shifting } \\
M L & =\text { Constant } \\
\alpha & =\text { Regression Coefficient } \\
\beta_{1}-\beta_{5} & =\text { Financial Distress } \\
F D & =\text { Proportion of Independent Board of Commissioners } \\
P D K I & =\text { Proportion of Audit Committee } \\
P K A & =\text { Error/other variables not identified in the model } \\
\varepsilon &
\end{array}
$$

\section{Results and discussion}

\subsection{Descriptive statistics}

Descriptive statistics provide an overview of the research objects sampled including the mean, median, maximum, minimum, and standard deviation. The variables used in this study are earnings management (classification shifting) (Y), financial distress (X1), the independent board of commissioners (M1), and the audit committee (X2). The following shows the results of the descriptive statistical test for each variable in Table 1 below:

Table 1

The results of some basic statistics

\begin{tabular}{lcccc}
\hline & $\mathrm{N}$ & Minimum & Maximum & Mean \\
\hline ML & 185 & -17244500000000 & 14439800000000 & -321512917285.14 \\
FD & 185 & -4.2490 & .7600 & -1.653768 \\
DKI & 185 & .2500 & 5.0000 & .714865 \\
KA & 185 & 2.0000 & 6.0000 & 3.081081 \\
\hline
\end{tabular}

Secondary Data, 2021

Based on Table 1, it can be explained that the ML variable consists of 185 samples of observations with the lowest earnings management value of $-17,244,500,000,000$ and the highest of 14,439,800,000,000, where the minimum value was achieved in 2016 and the maximum value was in 2019. Average value -The average (mean) in this variable is $-321,512,917,285.14$ and the standard deviation value is $922,337,203,685.48$. Standard deviation greater than the mean indicates that the data are heterogeneous. The number of financial distress variables is 185 observation samples with a minimum value of -4.2490 , while the highest value is 0.7600 . The average (mean) value for this variable is -1.653768 and the standard deviation value is 1.1283296. Standard deviation greater than the mean indicates that the data are heterogeneous. The variable of the independent board of commissioners is 185 observation samples with a minimum value of 0.25 and a maximum value of 5.00. The average value (mean) is 0.714865 and the standard deviation value is 0.5123137 . The standard deviation value that is smaller than the mean indicates that the data is homogeneous. The audit committee variable consists of 185 observation samples with a minimum value of 2.00 and a maximum value of 6.00 . The average value (mean) is 3.081081 and the standard deviation value is 0.5096023 . The standard deviation value that is smaller than the mean indicates that the data is homogeneous.

\subsection{Classical assumption}

\section{Normality test}

The probability value in this study was $0.00(0.00<0.05)$, which means that the data is not distributed normally. However, to overcome this, it can use the Assumption of Central Limit Theorem. Simply put, if the number of observations is large enough $(\mathrm{n}>30)$, then the assumption of normality can be ignored (Gujarati \& Malindasari et al., 2016). In this study the number of samples was 185 , so the data is assumed to be normally distributed. 
Table 2 shows the results of multicollinearity test.

Table 2

The summary of collinearity statistics

\begin{tabular}{lrr}
\hline & Collinearity Statistics \\
\cline { 2 - 3 } Financial Distress $\left(\mathrm{X}_{1}\right)$ & Tolerance & VIF \\
Independent Board of Commissioners $\left(\mathrm{M}_{1}\right)$ &, 894 & 1,118 \\
Audit Committee $\left(\mathrm{M}_{2}\right)$ &, 984 & 1,017 \\
\hline
\end{tabular}

Secondary Data, 2021

Based on Table 2, the tolerance value is above 0.10 and the VIF value is below 10 , so it can be concluded that the data in this study do not contain symptoms of multicollinearity.

Heteroscedasticity Test

Table 3 presents the results.

Table 3

The summary of the heteroscedasticity test

\begin{tabular}{cccc}
\hline & Value & Df & Probabilities \\
\hline Likelihood Ratio & 1,831135 & 37 & 1,000 \\
\hline Secondary Data, 2021 & &
\end{tabular}

Secondary Data, 2021

Based on Table 3, it is known that the probability value of F-Count is greater than 0.05 so it can be concluded that there is no heteroscedasticity in the research data used.

Autocorrelation Test

The value of DW (Durbin Watson) is 1.987 , with several samples $(\mathrm{N})$ as many as 185 , a significance level of 0.05 , variable $(\mathrm{k}=5)$, then the values of $\mathrm{dL}=1.704$ and $\mathrm{dU}=1.815$. The result is a $\mathrm{DW}$ of 1.987 greater than the upper limit $(\mathrm{dU}) 1.815$ and less than the 4 -upper limit (4-dU) 2.185 or $1.815<1.987<2.185$. From these results it can be concluded that the regression model of this study is free from autocorrelation.

Panel test

Next step is to examine the effect of Panel test. Table 4 presents the summary of the results.

Table 4

The summary of Chow test

\begin{tabular}{lll}
\hline & Effects Test & Prob \\
\hline Cross-Section F & & .0000 \\
Cross-Section Chi-square & .0000 \\
\hline
\end{tabular}

Secondary Data, 2021

Decision making based on the Chow Test is if the probability value of Cross Section F is less than the value of $(\alpha=0.05)$, then the correct panel data regression method to choose is Fixed Effect Model (FEM). The test results in Table 4 show the probability values of the cross section $\mathrm{F}$ of $0.00<0.05$, so the right panel data regression method to choose is the Fixed Effect Model (FEM). In addition, Table 5 presents the results of Hausman test.

Table 5

The summary of Hausman test

\begin{tabular}{ccc}
\hline Test Summary & Chi Square Statistic & Probabilities \\
\hline Cross-section Random & 16.407309 & 0.0058 \\
\hline
\end{tabular}

Secondary Data, 2021

The Hausman test uses a Chi-square distribution with the condition that if the probability value is $<0.05$, the regression model used is the fixed effect model. Based on Table 5, it is known that the probability value resulting from the Hausman Test is smaller than the alpha $(\alpha)$ value, which is $0.0058<0.05$. Therefore, the right panel data regression method to choose is the Fixed Effect Model (FEM).

\section{Panel Data Moderation Regression Test}

Based on the results of calculations using Eviews, the results of the moderating regression test are obtained as in Table 6 below. 
Table 6

The summary of the regression analysis

\begin{tabular}{lccc}
\hline Variabel & Coefficients & Std. Error & t- Statistic \\
\hline (Constant) & 27.14043 & 0.335071 & 80.99909 \\
FD (X1) & 1.044564 & 0.044768 & 23.33294 \\
DKI (M1) & 0.906082 & 0.812712 & 1.114887 \\
KA (M2) & -22.88040 & 0.651576 & -35.11550 \\
FD_DKI & -0.032609 & 0.031353 & -1.040055 \\
FD_KA & 0.834977 & 0.021864 & 0.2668 \\
Adjusted R Square & 0.980575 & & 0.0000 \\
F & 227.5423 & & 0.3001 \\
Sig. F & 0.000000 & & 0.0000 \\
\hline
\end{tabular}

From the results of the calculations in Table 4 above, the moderating regression equation can be arranged as follows,

$$
Y=27.14043+1.044564 F D+0.906082 D K I-22.88040 K A-0.032609 F D \_D K I+0.834977 F D \_K A
$$

The equation above can illustrate that if financial distress, independent board of commissioners, audit committee, and the interaction between financial distress with independent board of commissioners and audit committee is 0 or equal to constant, then the value of earnings management is 27.14043. Furthermore, if financial distress has increased by one unit, then the value of earnings management has increased by 1.044564 with an independent board of commissioners and an audit committee of 0 . Then, the interaction between financial distress and an independent board of commissioners is negative at -0.032609 . This illustrates that for every one unit increase in the independent board of commissioners variable, earnings management will decrease by -0.032609 . Furthermore, the interaction between financial distress and the audit committee has a positive value of 0.834977 . This illustrates that for every one unit increase in the audit committee variable, earnings management will increase by 0.834977

\section{Coefficient of Determination (Adj. $\left.R^{2}\right)$}

The value of the coefficient of determination can be shown by the adjusted R-Square value. Based on Table 4 the resulting adjusted R-Square value is 0.980575 . This shows that $98 \%$ of the variation in earnings management is influenced by financial distress (X1), interaction of financial distress with independent commissioners (X1_M1), and interaction of financial distress with the audit committee (X1_M2), while the remaining $2 \%$ is influenced by other variables. not explained in this study.

\section{Model Feasibility Test (F Test)}

The $\mathrm{F}$ test is used to determine whether the regression model is feasible to use to explain the effect of the independent variables on the dependent variable. Based on Table 4 the calculated $\mathrm{F}$ value is 227.5423 with a significance level of 0.000 $(0.000<0.005)$ this means that the model used in this study is feasible to use in research. This means that financial distress simultaneously affects earnings management.

\section{Hypothesis Test ( $t$ Test)}

The $t$ test is used to determine whether the independent variable has a partial effect on the dependent variable. To determine whether the hypothesis is accepted or rejected is to look at the significance value in this study using a significance level of 0.05 .

\section{The Effect of Financial Distress on Earnings Management Practices Using Classification Shifting}

The first hypothesis states that financial distress affects earnings management practices using classification shifting. Based on the results of the analysis, the regression coefficient X1 is 0.974642 with a significance level of 0.000 which is smaller than the 0.05 level of significance, so it can be concluded that the first hypothesis is accepted, which means that when the property, real estate, and building construction sector companies are listed on the Stock Exchange The Indonesian Stock Exchange (IDX) is experiencing financial distress, so managers will practice earnings management. The results of this study are consistent with the results of research from Husnaini and Cahyaningtyas (2017), Chiorean et al. (2017), and Nagar and Sen(2017), where the study also provides empirical evidence that financial distress affects earnings management practices using classification shifting. Financial distress is a condition where the company is no longer able to fulfill its obligations as a debtor because it is in a state of shortage and insufficient funds to run its business. Feldo et al., (2019) said that financial distress occurred before the company went bankrupt. With financial distress, management is expected to be able to take actions to anticipate these conditions. Practical actions to anticipate financial distress by performing earnings management manajemen (Supardi \& Asmara, 2019). 
The results of this study can be explained by the agency theory expressed by Jensen and Meckling (1976). When a company experiences financial distress, management is certainly required to find the best way to save the company from this condition. At this time there is an agency problem, where both parties have different interests. Management as an agent should be on behalf of the best interest of the shareholders, but on the other hand, management wants to prioritize its own interests to maximize utility. Koch in Feldo et al., (2019) states that earnings management behavior will increase as the company's financial distress level increases, therefore this earnings management practice is expected to be able to save the company. The decision of the manager (agent) to take this action is certainly more profitable from the manager's side. First, managers tend to do earnings management to hide their poor performance. Second, by carrying out earnings management, managers have the potential to get bonuses or maintain their positions because they are considered capable by investors to maintain or even improve the company's financial performance. The manager's actions of course only benefit personal interests and do not think about the bad impact for the company in the future. In this case the agent will try to maximize his own interests and ignore the interests of the principal even though the main goal of a company is to maximize the welfare of the owners of capital.

\section{The Influence of the Independent Board of Commissioners in Weakening the Effect of Financial Distress on Earnings Management Practices Using Classification Shifting}

The second hypothesis states that the influence of independent commissioners in weakening the influence of financial distress on earnings management practices uses classification shifting. Based on the results of the analysis, the regression coefficient X1_M1 is -0.032609 with a significance level of 0.3001 which is greater than the 0.05 significance level, so it can be concluded that the second hypothesis is rejected, which means that the independent board of commissioners is unable to moderate or unable to weaken or strengthen the effect of financial distress on earnings management practices using classification shifting in property, real estate, and building construction sector companies listed on the Indonesia Stock Exchange (IDX). The results of this study support the results of research from Johari et al., (2009), Putri and Rachmawati (2018), Rosellyn and Harapan (2019), Lippolis and Grimaldi (2015), but it contradicts the results of research from Busirin et al., (2015) and Hartomo (2016). The board of commissioners is the highest internal control mechanism in the company consisting of two members of the board of commissioners, one of which is an independent board of commissioners. Based on POJK No. 33 of 2014, the proportion of independent commissioners is required to be at least 30 percent of the total members of the board of commissioners who are affiliated with issuers or members of the company's directors or shareholders. The results of the statistical research in Table 1 show the average value of the independent board of commissioners of 71.48 percent. This value reflects that although the average independent board of commissioners has exceeded that required by the OJK, in fact the independent board of commissioners is still not able to minimize earnings management practices when the company is in financial distress. This value seems to indicate that the composition of the proportion of independent commissioners solely to fulfill formal requirements is not intended to enforce good corporate governance. The results of this study do not support the agency theory proposed by Jensen and Meckling (1976). Agency costs are costs that must be incurred by the principal because of the relationship between the principal and agent, one of which is the cost of monitoring through an independent board of commissioners. However, even though the principal has tried to control the behavior and actions of agents, in fact the independent board of commissioners is still not able to suppress or reduce earnings management practices.

\section{The Effect of the Audit Committee in Weakening the Effect of Financial Distress on Earnings Management Practices Using Classification Shifting}

The third hypothesis states that the influence of the audit committee in weakening the effect of financial distress on earnings management practices uses classification shifting. Based on the analysis results, the regression coefficient X1_M2 is 0.834977 with a significance level of 0.0000 which is smaller than the 0.05 level of significance. Based on this, H3 is rejected. It can be concluded that the audit committee strengthens the effect of financial distress on earnings management practices using classification shifting in property, real estate, and building construction sector companies listed on the Indonesia Stock Exchange (IDX). The results of this study are consistent with research from Wiyadi et al. (2019), Satrio et al., (2018), and Oktaviani (2016). This result is also strengthened by the statistical results in Table 1 which shows that the average value for the proportion of audit committees is 3.081. This value is in accordance with the minimum amount set by OJK, but the audit committee strengthens earnings management practices when the company is in financial distress. Wiyadi et al., (2019) revealed that this could be due to the possibility that the formation of an audit committee within the company was based on meeting the basic legal framework in Indonesia. Other than that, Effendi in Wiyadi et al., (2019) reaffirmed that the selection of the audit committee is likely to be based more on proximity to the company's board of commissioners, so that members of such an audit committee are difficult to expect to work professionally. The results of this study are also not in accordance with the agency theory proposed by Jensen and Meckling (1976). Agency costs are costs that must be incurred by the principal because of the relationship between the principal and the agent. One of them is the cost of monitoring. The establishment of an audit committee that is expected to at least be able to help the board of commissioners to weaken earnings management practices, but in fact still not able to reduce earnings management practices. 


\section{Conclusion}

The higher the financial distress condition, the more likely it is for earnings management practices to occur in property, real estate, and building construction sector companies listed on the Indonesia Stock Exchange (IDX) in 2015-2019. The independent board of commissioners is unable to moderate the effect of financial distress on earnings management practices using classification shifting, while the audit committee strengthens earnings management practices when companies in the property, real estate, and building construction sectors are listed on the Indonesia Stock Exchange (IDX) in 2015- 2019 experienced financial distress. Future research is expected to be able to use companies in different sectors, expand the research period, use other variables that may affect earnings management practices by using classification shifting as an earnings management tool.

\section{References}

Abbadi, S. S., Hijazi, Q. F., \& Al-Rahahleh, A. S. (2016). Corporate governance quality and earnings management: Evidence from Jorand. Australasian Accounting, Business and Finance Journal, 10(2), 54-75.

Amelia, W., \& Hernawati, E. (2016). Pengaruh Komisaris independen, ukuran perusahaan and profitabilitas terhadap manajemen laba. Neo-Bis, 10(1), 62-77.

Astika, I. B. P. (2010). Manajemen Laba and Motif yang Melandasinya. Jurnal Ilmiah Akuntansi and Bisnis, 5(1).

Busirin, M. F., Azmi, N. A., \& Zakaria, N. B. (2015). How Effective is Board Independence to the Monitoring of Earnings Manipulation?. Procedia Economics and Finance, 31, 462-469.

Cahyaningtyas, S. R., Husnaini, W., Hendri, R. S., Ramadhani, R. S., Lenap, I. P. \& Campa, D. (2019). Earnings management strategies during financial difficulties: A comparison between listed and unlisted French companies. Research in International Business and Finance, 50, 457-471.

Chiorean, R., Kirschenheiter, M., \& Ramakrishnan, R. T. (2017). Earnings Management Through OCI Components. Available at SSRN 2947818.

Chrisdianto, B. (2013). Peran komite audit dalam good corporate governance. Jurnal Akuntansi Aktual, 2(1), 1-8.

Damayanti, C. R., \& Kawedar, W. (2018). Pengaruh Profitabilitas, Mekanisme Pemantauan and Financial Distress Terhadap Manajemen Laba (Doctoral dissertation, Fakultas Ekonomika and Bisnis).

Davidson, R., Goodwin-Stewart, J., \& Kent, P. (2005). Internal governance structures and earnings management. Accounting \& Finance, 45(2), 241-267.

Debbianita, D., Siregar, S. V., \& Adhariani, D. (2016). Manajemen Laba Menggunakan Classification Shifting and Kualitas Audit. Jurnal Keuangan and Perbankan, 20(2), 178843.

Dewi, K. R. C., Rasmini, N. K., \& Ratnadi, N. M. D. The Effect of Independent Board of Commissioners, Institutional Ownership, and Managerial Ownership in Firm Values with Environmental Disclosure as Moderating Variable.

Dwiyanti, K. T., \& Astriena, M. (2019). Pengaruh Kepemilikan keluarga and Karakteristik Komite Audit Terhadap Manajemen Laba. Jurnal Riset Akuntansi And Bisnis Airlangga, 3(2).

Feldo, F., \& Yuliati, R. (2019). Hubungan Kesulitan Keuangan Dengan Manajemen Laba Pada Perusahaan Yang Terdaftar Di Bursa Efek Indonesia Tahun 2010-2016. Equity, 21(2), 141-151.

Ghazali, A. W., Shafie, N. A., \& Sanusi, Z. M. (2015). Earnings management: An analysis of opportunistic behaviour, monitoring mechanism and financial distress. Procedia Economics and Finance, 28, 190-201.

Gunawan, F. F., Rudiawarni, F. A., \& Sutanto, A. C. (2014). Hubungan antara financial distress dengan earnings management pada baand usaha sektor manufaktur yang terdaftar di bei periode 2010-2012. CALYPTRA, 3(1), 1-18.

Gupta, A. T., \& Suartana, I. W. (2018). Pengaruh financial distress and kualitas corporate governance pada manajemen laba. E-Jurnal Akuntansi Universitas Udayana, 23(2), 26.

Hartomo, A. B. (2015). Keberadaan Corporate Governance sebagai Variabel Moderasi Pengaruh Financial Distress terhadap Earnings Management (Pada Perusahaan yang Terdaftar di Bursa Efek Indonesia) (Doctoral dissertation, Perpustakaan STIE YKPN).

Idris, M., Siam, Y. A., \& Nassar, M. (2018). Board independence, earnings management and the moderating effect of family ownership in Jorand. Management \& Marketing. Challenges for the Knowledge Society, 13(2), 985-994.

Jacoby, G., Li, J., \& Liu, M. (2019). Financial distress, political affiliation and earnings management: the case of politically affiliated private firms. The European Journal of Finance, 25(6), 508-523.

Jensen, M. C., \& Meckling, W. H. (1976). Theory of the firm: Managerial behavior, agency costs and ownership structure. Journal of financial economics, 3(4), 305-360.

Johari, N. H., Saleh, N. M., Jaffar, R., \& Hassan, M. S. (2009). The influence of board independence, competency and ownership on earnings management in Malaysia. The influence of board independence, competency and ownership on earnings management in Malaysia. International Journal of Economics and Management, 2 (2), 281-306.

Kanakriyah, R., Shankat, M. M., \& Freihat, A. R. M. S. (2017). Exploitation of earnings management concept to influence the quality of accounting information: Evidence from Jorand. Research Journal of Finance and Accounting, 8(22), 5361.

Kazemian, S., Shauri, N. A. A., Sanusi, Z. M., Kamaluddin, A., \& Shuhiand, S. M. (2017). Monitoring mechanisms and financial distress of public listed companies in Malaysia. Journal of International Studies, 10(1).

Kurniawati, A., \& Panggabean, R. R. (2020). Firm Size, Financial Distress, Audit Quality, and Earnings Management of 
Banking Companies. Kurniawati, A. and Panggabean, RR, Firm Size, Financial Distress, Audit Quality, and Earnings Management of Banking Companies. Advances in Social Science, Education and Humanities Research, 436, $413-417$.

Li, Y., Li, X., Xiang, E., \& Djajadikerta, H. G. (2020). Financial distress, internal control, and earnings management: Evidence from China. Journal of Contemporary Accounting \& Economics, 16(3), 100210.

Lippolis, S., \& Grimaldi, F., (2015). Corporate governance e politiche di Earnings Management: aspetti teorici ed evidenze empiriche. Corporate governance e politiche di Earnings Management, 1-151.

Malindasari, P., Sukartha, I. M., \& Wirakusuma, M. G. (2016). PENGARUH DEPRESIASI NILAI RUPIAH PADA RETURN SAHAM AND VOLUME PERDAGANGAN SAHAM PERUSAHAAN MULTINASIONAL DI BURSA EFEK INDONESIA. E-Jurnal Ekonomi and Bisnis Universitas Udayana.

Mansor, N., Che-Ahmad, A., Ahmad-Zaluki, N. A., \& Osman, A. H. (2013). Corporate governance and earnings management: A study on the Malaysian family and non-family owned PLCs. Procedia Economics and Finance, 7, 221229.

Marsha, F., \& Ghozali, I. (2017). Pengaruh ukuran komite audit, audit eksternal, jumlah rapat komite audit, jumlah rapat dewan komisaris and kepemilikan institusional terhadap manajemen laba (studi empiris perusahaan manufaktur yang terdaftar di bei tahun 2012-2014). Diponegoro Journal of Accounting, 6(2), 91-102.

McVay, S. E. (2006). Earnings management using classification shifting: An examination of core earnings and special items. The Accounting Review, 81(3), 501-531.

Nagar, N., \& Sen, K. (2017). Do financially distressed firms misclassify core expenses?. Accounting Research Journal.

Noviantari, N. W., \& Ratnadi, N. M. D. (2015). Pengaruh financial distress, ukuran perusahaan, and leverage pada konservatisme akuntansi. E-Jurnal Akuntansi, 11(3), 646-660.

Oktaviani, H. D. (2016). Pengaruh Ukuran Dewan Direksi, Proporsi Dewan Komisaris Independen, and Ukuran Komite Audit Terhadap Praktik Manajemen Laba Pada Perusahaan Farmasi yang Terdaftar di BEI Tahun 2009-2014. Jurnal Akuntansi AKUNESA, 4(2).

Putri, B. N. L., \& Rachmawati, S. (2019). Analisis Financial Distress and Free Cash Flow dengan Proporsi Dewan Komisaris Independen sebagai Variabel Moderasi Terhadap Manajemen Laba. Jurnal Keuangan and Perbankan, 14(2), 54-61.

Ranjbar, S., \& Amanollahi, G. (2018). The effect of financial distress on earnings management and unpredicted net earnings in companies listed on Tehran Stock Exchange. Management Science Letters, 8(9), 933-938.

Rosellyn A, N., \& Lusmeida, H. (2019). The Impact of firm and board characteristics towards earnings management.

Satrio, A., Oktaroza, M. L., \& Purnamasari, P. (2019). Pengaruh Kualitas Audit and Komite Audit terhadap Manajemen Laba.

Supardi, S., \& Asmara, E. N. (2019, May). Financial Factors, Corporate Governance and Earnings Management: Evidence from Indonesian manufacturing industry. In 1st International Conference on Economics, Business, Entrepreneurship, and Finance (ICEBEF 2018) (pp. 727-736). Atlantis Press.

Wiyadi, W., Trisnawati, R., \& Sulistyowati, E. (2019). MEKANISME CORPORATE GOVERNANCE AND MANAJEMEN LABA MODEL LONG TERM DISCRETIONARY ACCRUAL PADA PERUSAHAAN GO PUBLIK DI INDONESIA. Jurnal Manajemen Dayasaing, 21(1), 55-69.

Zalata, A., \& Roberts, C. (2016). Internal corporate governance and classification shifting practices: An analysis of UK corporate behavior. Journal of Accounting, Auditing \& Finance, 31(1), 51-78.

Zehri, F., \& Zgarni, I. (2020). Internal and external corporate governance mechanisms and earnings management: an international perspective. Accounting and Management Information Systems, 19(5), 33-64. 
(C) 2022 by the authors; licensee Growing Science, Canada. This is an open access article distributed under the terms and conditions of the Creative Commons Attribution (CC-BY) license (http://creativecommons.org/licenses/by/4.0/). 